\title{
FENOMENA PRAGMATIS DALAM AL-QUR'AN: ANALISIS TINDAK TUTUR ILOKUSI PADA PERCAKAPAN MUSA A.S. DAN KHIDIR
}

\author{
Rizza Faesal Awaludin, Ika Wahyu Susiani \\ Institut Agama Islam Sunan Giri (INSURI) Ponorogo \\ e-mail:kathonk.rizza@gmail.com,ikawahyususiani@gmail.com
}

\begin{abstract}
The studies of Qur'an have been carried out by many researchers, including studies conducted on the story of Khidir with the prophet Moses peace be upon him. However, none of the studies specifically examined it through pragmatic review. This research aims to reveal the types of ilocutionary act contained in the conversation between the prophet Musa and Khidir. This research uses a qualitative approach that is descriptive through a literature review. Analysis of the conversation between the prophet Moses peace be upon him and Khidir reveals the existence of three types of ilocutionary act, directive (ask, demand, plead, and suggest), commisive (promise and offer), and declarative (determine and give punishment). With the disclosure of these types of ilocutionary act, it is expected to provide a new perspective in looking at the friendship story of the two righteous servants of Allah.
\end{abstract}

Keyword: pragmatic phenomenon, ilocutionary act, the conversation of the prophet Moses peace be upon him and Khidir

\section{A. Pendahuluan}

Al-Qur'an merupakan firman Allah yang berupa mukjizat, diturunkan kepada Nabi Muhammad saw., tertulis dalam mushaf yang disampaikan secara mutawatir dan bagi yang membacanya dinilai ibadah. Firman tersebut dimulai dari Surah al-Fatihah dan diakhiri dengan Surah al-Nas. ${ }^{1}$ Definisi tersebut secara eksplisit menempatkan alQur'an sebagai kitab suci umat Islam.

Sebagai kitab suci yang menjadi pedoman hidup umat Islam, al-Qur'an yang tersusun atas 114 surah tersebut tidak hanya memuat hukum-hukum aqidah dan syariah, tetapi juga menjelaskan dasar-dasar ilmu pengetahuan, pendidikan, akhlak serta aspekaspek lain yang mereka butuhkan dalam menjalani kehidupan, baik secara langsung maupun melalui kisah-kisah yang diabadikan di dalamnya. Di antara kisah-kisah dalam al-Qur'an yang syarat akan hikmah dan pelajaran serta sangat populer dalam khazanah cerita para nabi, bahkan melebihi nabi-nabi selain nabi Muhammad Saw. adalah kisah Khidir bersama nabi Musa a.s. ${ }^{2}$

\footnotetext{
${ }^{1}$ Fathurrosyid, "Pragmatika al-Qur'an: Model Pemahaman Kisah Maryam yang Terikat Konteks," Jurnal Suhuf, Vol. 9 No. 2 (Desember, 2016), 325.

${ }^{2}$ M. Faisol, "Struktur Naratif Cerita Nabi Khidir dalam al-Qur'an," Adabiyyat, Vol. X No.2 (Desember, 2011), 235-236.
} 
Khidir adalah hamba yang shalih yang Allah anugerahi karamah berupa ilmu ghaib. Ilmu tersebut merupakan ilmu khusus yang tidak diajarkan kecuali atas bimbingan serta pertolongan-Nya. ${ }^{3}$ Allah memerintahkan nabi Musa a.s. untuk belajar kepada beliau tentang bersikap tawadhu' atas ilmu. ${ }^{4}$ Kisah pertemanan antara dua hamba Allah yang shalih ini telah banyak dikaji oleh para peneliti, baik dari segi pesan yang disampaikan maupun cara penyampaiannya. Namun, dari banyaknya penelitianpenelitian tersebut belum ada yang mengkajinya secara khusus melalui tinjauan pragmatik.

Pragmatik adalah cabang ilmu bahasa yang mempelajari struktur bahasa secara eksternal, yakni bagaimana satuan kebahasaan digunakan dalam berkomunikasi. Yang dimaksud dengan studi kebahasaan secara eksternal di sini adalah studi bahasa yang mempelajari relasi bahasa dengan konteksnya. Konteks memiliki peranan kuat dalam menentukan maksud penutur dalam berinteraksi dengan lawan tutur. Jadi, dapat dipahami bahwa pragmatik mengkaji makna yang dimaksud oleh penutur bukan makna yang dimuat oleh ujaran penutur. Dengan demikian, pragmatik tidak berurusan dengan what does $x$ mean? Tetapi mengkaji what did you mean by $x ?^{5}$

Dalam mengkaji al-qur'an secara pragmatis, terdapat beberapa teori yang dapat digunakan salah satunya adalah teori tindak tutur yang meliputi tindak lokusi, ilokusi dan perlokusi. Tindak lokusi merupakan tindak tutur yang menyatakan sesuatu sebagaimana yang dikendaki oleh wujud formalnya. Tindak ilokusi adalah tindak tutur yang tidak hanya berfungsi mengatakan atau menginformasikan sesuatu, tetapi juga melakukan sesuatu. Sedangkan tindak perlokusi adalah tindak tutur yang mempunyai daya pengaruh bagi petuturnya. ${ }^{6}$

Berdasarkan latar belakang di atas, maka perlu diadakan kajian terhadap kisah nabi Musa a.s. bersama Khidir melalui tinjauan pragmatik guna memberikan perspektif baru dalam memandang kisah tersebut. Pada penelitian ini, kajian terhadap kisah tersebut difokuskan pada pengungkapan jenis-jenis tindak tutur ilokusi yang terdapat pada percakapan antara nabi Musa a.s. dan Khidir.

\section{B. Pragmatik dalam Al-Qur'an}

\footnotetext{
${ }^{3}$ Muhammad Ali al-Shabuni, Shafwatu al-Tafasir Juz 2 (Beirut: Dar al-Fikri, 1996), 182.

${ }^{4}$ Wahbah al-Zuhailiy, al-Tafsir al-Munir Jilid 8 (Damaskus: Dar al-Fikri, 2009), 324.

${ }^{5}$ Faiq Ainur Rofiq, "Analisa Redaksi Tindak Tutur Imperatif dalam Surat al-Baqarah,” Jurnal Kodifikasia, Vol. 9 No. 1 (2015), 246.

${ }^{6}$ Mardjoko Idris, Stilistika al-Qur'an: Kajian Pragmatik (Yogyakarta: KaryaMedia, 2013), 31-32.
} 


\section{Pengertian pragmatik}

Istilah pragmatik, telah dikenal sejak lama yaitu sejak masa hidupnya filsuf ternama Charles Morris dalam kajiannya terhadap ilmu tanda dan ilmu lambang yang disebut dengan semiotik. Dengan mendasarkan pemikirannya pada gagasan filsuf-filsuf pendahulunya seperti Charles Sanders Pierce dan John Locke, ia membagi ilmu tanda dan ilmu lambang tersebut ke dalam tiga cabang, yakni sintaksis, semantik dan pragmatik. Sintaksis mengkaji hubungan formal tandatanda, semantik mengkaji hubungan antara tanda-tanda dengan objeknya, sedangkan pragmatik mengkaji hubungan antara tanda-tanda dengan penafsirnya. Dari sinilah lahir ilmu pragmatik di bumi linguistik. ${ }^{7}$

Sejak kelahirannya di bumi linguistik tersebut, pragmatik mendapat perhatian dari berbagai pakar yang kemudian menyebabkan munculnya definisi beragam sesuai dengan latar belakang serta kecenderungan masing-masing. Geoffrey Leech misalnya, mengartikan pragmatik sebagai telaah terhadap makna dalam hubungannya dengan penutur atau pemakai bahasa. ${ }^{8}$

Tokoh lain, Levinson memaknai pragmatik sebagai telaah mengenai relasi antara bahasa dengan konteks yang merupakan dasar bagi suatu laporan pemahaman bahasa. ${ }^{9}$ Studi ini melibatkan penafsiran tentang apa yang dimaksud seseorang dalam suatu konteks tertentu dan bagaimana konteks tersebut berpengaruh terhadap apa yang dikatakan. Dengan demikian, pragmatik melihat manakah yang merupakan konteks dari suatu ujaran dan menelaah ucapan-ucapan tertentu dalam situasi-situasi tertentu serta memusatkan perhatian pada berbagai cara performansi bahasa yang merupakan wadah berbagai konteks sosial. ${ }^{10}$

Lebih jauh, George Yule mendefinisikan pragmatik sebagai suatu studi tentang hubungan antara bentuk-bentuk linguistik dan pemakai bentuk-bentuk tersebut. Definisi tersebut menempatkan pragmatik sebagai suatu studi dengan empat ruang lingkup, yakni studi tentang maksud penutur, studi tentang makna

\footnotetext{
${ }^{7}$ Moch Sony Fauzi, Pragmatik dan Ilmu Ma'aniy: Persinggungan Ontologik dan Epistemologik (Malang: UIN Maliki Press, 2012), 4.

${ }^{8}$ Geoffrey Leech, Prinsip-prinsip Pragmatik, terj. M.D.D. Oka (Jakarta: Universitas Indonesia (UI Press), 2015), 8.

${ }^{9}$ Idris, Stilistika al-Qur'an: Kajian Pragmatik, 18.

10 Tadkiroatun Musfiroh, Psikolinguistik Edukasional: Psikolinguistik untuk Pendidikan Bahasa (Yogyakarta: Tiara Wacana, 2017), 78.
} 
kontekstual, studi tentang bagaimana agar lebih banyak yang disampaikan daripada yang dituturkan dan studi tentang ungkapan dari jarak hubungan. ${ }^{11}$

Senada dengan definisi yang diberikan oleh para pakar linguistik barat di atas, Bambang Kaswanti Purwo salah seorang pakar linguistik Indonesia memaknai pragmatik sebagai telaah tentang makna tuturan, yang mana makna tersebut terikat oleh konteks. Sementara I Dewa Putu Wijana menetapkan pragmatik sebagai cabang linguistik yang mempelajari struktur bahasa secara eksternal meliputi penggunaan bahasa dalam konteks sosial dan dalam penggunaan nyata, yang maknanya ditentukan oleh para pelibat tuturan. ${ }^{12}$

Dari berbagai definisi yang dikemukakan oleh para pakar linguistik baik pakar linguistik barat maupun pakar linguistik timur di atas, dapat ditarik benang merah bahwasanya pragmatik merupakan telaah terhadap makna tuturan dalam kaitannya dengan konteks yang melingkupi tuturan tersebut. Adapun konteks dalam penelitian ini meliputi faktor-faktor yang melatarbelakangi tuturan itu diucapkan yang biasa disingkat dengan SPEAKING.

\section{Tindak tutur dan pengklasifikasiannya}

Salah satu fenomena ilmu bahasa pragmatik yang dapat digunakan untuk menganalisis makna kalimat adalah tindak tutur (speech act). Tindak tutur merupakan gejala individu yang bersifat psikologis dan keberlangsungannya ditentukan oleh kemampuan bahasa si penutur dalam menghadapi situasi tertentu. ${ }^{13}$ Ia adalah sepenggal tutur yang dihasilkan sebagai bagian dari interaksi sosial. ${ }^{14}$ Austin membagi tindak tutur ini menjadi tiga, yaitu ${ }^{15}$ :

a. Tindak lokusi (locutionary act), adalah tindak tutur yang menyatakan sesuatu sebagaimana yang dikendaki oleh wujud formalnya. Tindak tutur ini disebut dengan The Act of Saying Something.

b. Tindak ilokusi (ilocutionary act), merupakan tindak tutur dimana suatu tuturan selain berfungsi untuk mengatakan atau menginformasikan sesuatu, dapat juga dipergunakan untuk melakukan sesuatu. Tindak tutur ini disebut sebagai The Act of Doing Something.

\footnotetext{
${ }^{11}$ George Yule, Pragmatik, terj. Indah Fajar Yuni dan Rombe Mustajab (Yogyakarta: Pustaka Pelajar, 2006), 3-5.

${ }^{12}$ Musfiroh, Psikolinguistik Edukasional: Psikolinguistik untuk Pendidikan Bahasa, 80.

${ }^{13}$ Abdul Chair dan Leonie Agustina, Sosiolinguistik: Perkenalan Awal (Jakarta: Rineka Cipta, 2004$), 50$.

${ }^{14}$ Sumarsono, Sosiolinguistik (Yogyakarta: SABDA, 2011), 323.

${ }^{15}$ Idris, Stilistika al-Qur'an: Kajian Pragmatik, 31-32.
} 
c. Tindak perlokusi (perlocutionary act), dapat dipahami sebagai sebuah tuturan yang dituturkan oleh penutur yang mana tuturan tersebut mempunyai daya pengaruh atau efek bagi petuturnya. Tindak tutur ini disebut dengan The Act of Affecting Something.

Dengan kata lain, apabila seseorang mengucapkan sebuah kalimat ada kemungkinan terjadinya tiga jenis tindak tutur tersebut, yaitu lokusi, ilokusi dan perlokusi. Tindak tutur lokusi memiliki makna secara harfiah sebagaimana yang dimiliki oleh komponen-komponen kalimat yang ia ucapkan (mengacu pada makna linguistik). Tindak tutur dengan kalimat yang sama mungkin dipahami secara berbeda oleh pendengar. Makna sebagaimana ditangkap oleh pendengar inilah yang disebut sebagai tindak tutur ilokusi. Sebaliknya, pembicara pun sebenarnya mempunyai harapan bagaimana pendengar akan menangkap makna sebagaimana yang ia maksudkan. Makna inilah yang disebut dengan tindak tutur perlokusi. ${ }^{16}$

Selain tiga jenis tindak tutur di atas, Searle juga mengklasifikasikan tindak tutur ilokusi berdasarkan berbagai kriteria ke dalam lima jenis, yakni ${ }^{17}$ :

a. Asertif, merupakan tindak tutur ilokusi yang mengikat pembicara pada kebenaran proposisi yang diungkapkan, misalnya: menyatakan, memberitahukan, menyarankan, membanggakan, mengeluh, melaporkan dan sebagainya.

b. Direktif, merupakan tindak tutur ilokusi yang dimaksudkan untuk menghasilkan suatu efek berupa tindakan mitra tutur, misalnya: memesan, memerintahkan, memohon, menuntut, meminta, menyarankan, menganjurkan, menasihati dan sebagainya.

c. Komisif, merupakan tindak tutur ilokusi yang sedikit banyak mengikat penutur pada suatu tindakan di masa depan, misalnya: menjanjikan, bersumpah, menawarkan, memanjatkan (doa) dan sebagainya.

d. Ekspresif, merupakan tindak tutur ilokusi yang berfungsi untuk mengekspresikan, mengungkapkan, atau memberitahukan sikap psikologis sang penutur terhadap keadaan yang tersirat dalam ilokusi. Misalnya: mengucapkan terima kasih, mengucapkan selamat, memaafkan,

\footnotetext{
${ }^{16}$ Chaer, Sosiolinguistik: Perkenalan Awal, 53-54.

${ }^{17}$ Henry Guntur Tarigan, Pengajaran Pragmatik (Bandung: ANGKASA, 2009), 42-44. Lihat juga Leech, Prinsip-prinsip Pragmatik, terj. M.D.D. Oka, 163-166.
} 
mengampuni, menyalahkan, memuji, menyatakan belasungkawa dan sebagainya.

e. Deklaratif, adalah tindak tutur ilokusi yang jika performansinya berhasil akan menyebabkan kesesuaian antara isi proposisi dengan realitas. Contoh: menyerahkan diri, memecat, membebaskan, memberi nama, menamai, mengucilkan, mengangkat, menunjuk, menentukan, menjatuhkan hukuman, memvonis dan sebagainya.

\section{Faktor-faktor yang melatarbelakangi tindak tutur}

Dalam kajian pragmatik, tuturan tidak dapat dimaknai secara bebas dan terlepas dari konteks yang menyebabkan tuturan itu diucapkan. Ada berbagai faktor yang turut mendorong lahirnya suatu tuturan. Faktor-faktor tersebut dihimpun dalam sebuah akronim SPEAKING yang tersusun atas ${ }^{18}$ :

a. S: setting, yaitu tempat dan waktu terjadinya pertuturan, termasuk kondisi psikologis dan kultural yang menyangkut pertuturan tersebut

b. P: participants, adalah peserta tutur yang terdiri dari penutur dan mitra tutur

c. E: ends, menunjuk pada tujuan yang ingin dicapai dalam suatu situasi tutur

d. A: acts of sequence, mengacu pada saluran tutur yang dapat berupa lisan maupun tertulis

e. $\mathrm{K}:$ key, menunjukkan cara ataupun jiwa dari pertuturan yang dilangsungkan

f. I: instrumentalities, mengacu pada penggunaan kaidah bahasa dalam pertuturan

g. $\quad \mathrm{N}$ : norms, adalah norma atau aturan dalam berinteraksi

h. G: genre, mengacu pada kategori tuturan yang dapat berupa puisi, surat, artikel dan sebagainya.

\section{Analisis Tindak Tutur Ilokusi pada Percakapan nabi Musa a.s. dan Khidir}

\section{Sekilas tentang kisah nabi Musa a.s. dengan Khidir}

Kisah pertemanan nabi Musa a.s. dengan Khidir diabadikan dalam alQur'an surah al-Kahfi ayat 62-82. Berdasarkan hadits yang diriwayatkan oleh Imam Bukhari dan Imam Muslim, pertemanan antara keduanya berawal dari teguran Allah atas sikap nabi Musa a.s. yang tidak bersikap tawadhu' atas semua

\footnotetext{
${ }^{18}$ F.X. Nadar, Pragmatik \& Penelitian Pragmatik (Yogyakarta: Graha Ilmu, 2013), 7-8.
} 
ilmu yang Allah anugerahkan kepadanya hingga kemudian ia diperintahkan untuk belajar bersikap tawadhu' atas ilmu kepada Khidir. ${ }^{19}$

Khidir adalah hamba yang shalih yang Allah anugerahi karamah berupa ilmu ghaib. Ilmu tersebut merupakan ilmu khusus yang tidak diajarkan kecuali atas bimbingan serta pertolongan-Nya. ${ }^{20}$ Nama Khidir sendiri berasal dari kata khadr yang berarti hijau. Menurut riwayat yang datang dari Imam Bukhari melalui Abu Hurairah disebutkan nabi Muhammad Saw. bersabda bahwa penamaan itu disebabkan karena suatu ketika ia duduk di atas bulu yang berwarna putih, tetapi tiba-tiba warna bulu tersebut berubah menjadi hijau. M. Quraish Shihab berpendapat bahwa penamaan khidr merupakan simbol keberkahan yang dimiliki oleh seorang hamba seperti Khidir. ${ }^{21}$

Diceritakan dalam kisah tersebut bahwasanya nabi Musa a.s. ditemani pembantunya Yusa' bin Nun pergi ke arah pertemuan antara dua laut untuk menemui Khidir dan belajar kepadanya sebagaimana yang diperintahkan oleh Allah. Setelah mencarinya dengan susah payah akhirnya nabi Musa a.s. bertemu dengan Khidir dan menyampaikan maksud kedatangannya untuk belajar darinya ilmu yang tidak ia miliki. Atas kesungguhan nabi Musa a.s., akhirnya Khidir memperbolehkan nabi Musa a.s menemaninya dengan syarat tidak menanyakan apapun yang ia lakukan sampai dia sendiri yang menjelaskannya kepada nabi Musa a.s. ${ }^{22}$ Kisah pertemanan nabi Musa a.s. dengan Khidir dalam rangka menuntut ilmu ini diceritakan dalam bentuk percakapan yang oleh peneliti dianalisis melalui kaca mata tindak tutur sebagaimana pembahasan di bawah.

\section{Tindak tutur ilokusi pada percakapan nabi Musa a.s. dan Khidir}

Bentuk-bentuk tindak tutur ilokusi pada percakapan yang terjadi antara nabi Musa a.s. dan Khidir dapat dipaparkan sebagai berikut:

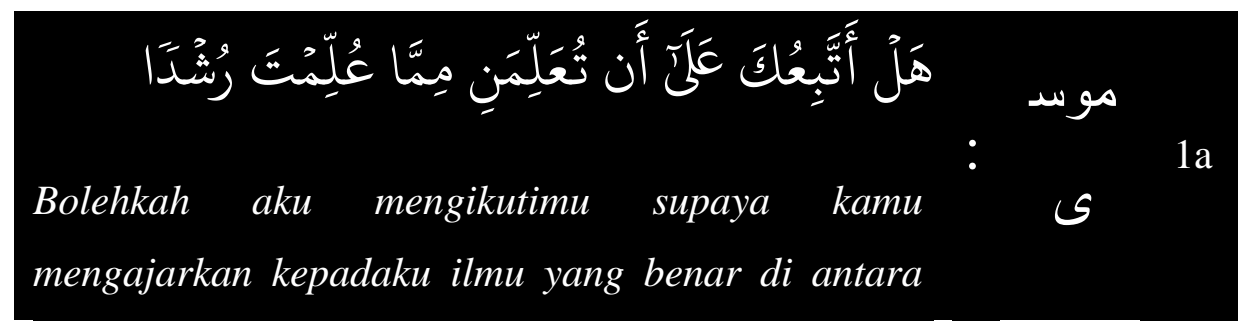

\footnotetext{
${ }^{19}$ al-Zuhailiy, al-Tafsir al-Munir Jilid 8, 317-318.

${ }^{20}$ al-Shabuni, Shafwatu al-Tafasir Juz 2, 182.

${ }^{21}$ M. Faisol, "Struktur Naratif Cerita Nabi Khidir dalam al-Qur'an," Adabiyyat, Vol. X No.2 (Desember, 2011), 236.

${ }^{22}$ al-Zuhailiy, al-Tafsir al-Munir Jilid 8, 317-323.
} 


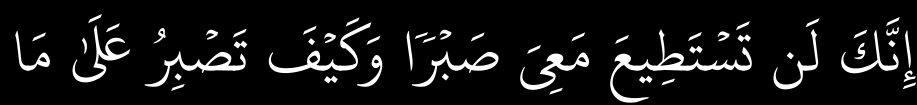

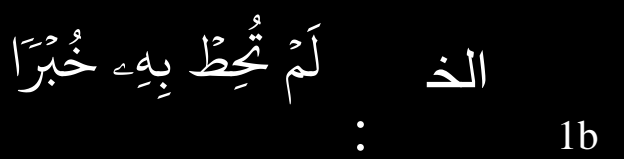

Sesungguhnya kamu sekali-kali tidak akan sanggup

sabar bersama aku. Dan bagaimana kamu dapat

sabar atas sesuatu, yang kamu belum mempunyai

pengetahuan yang cukup tentang hal itu?

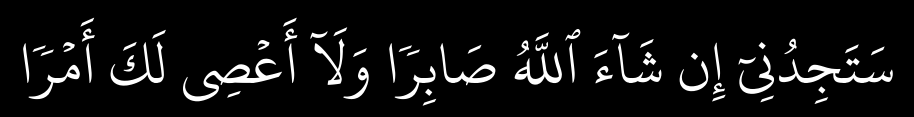

Insya Allah kamu akan mendapati aku sebagai orang :

yang sabar, dan aku tidak akan menentangmu dalam

sesuatu urusanpun

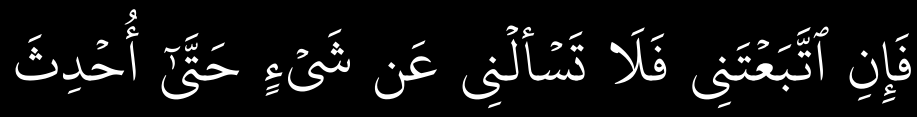

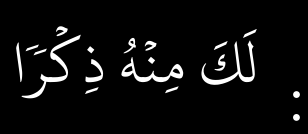

Jika kamu mengikutiku, maka janganlah kamu

menanyakan kepadaku tentang sesuatu apapun,

sampai aku sendiri menerangkannya kepadamu

Percakapan di atas terjadi ketika nabi Musa a.s. berhasil menemukan Khidir di dekat batu besar di tempat pertemuan dua laut. Pertemuan itu terjadi setelah nabi Musa a.s. bersama Yusa' bin Nun bersusah payah mencarinya untuk belajar ilmu yang bermanfaat dan amal shalih darinya. ${ }^{23}$ Dalam percakapan tersebut, nabi Musa a.s. berperan sebagai penutur dan Khidir sebagai mitra tutur. Tuturan (1a) termasuk tindak tutur ilokusi jenis direktif yang sifatnya meminta.

\footnotetext{
${ }^{23}$ Ibid., 320-322.
} 
Hal ini dapat diketahui dari tuturan penutur

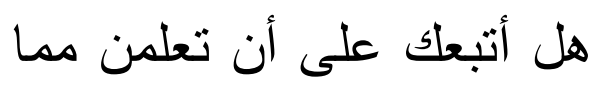
. Data tersebut memiliki maksud tuturan, nabi Musa a.s. meminta izin kepada Khidir agar ia diperbolehkan untuk mengikutinya supaya ia (Khidir) mengajarinya ilmu yang bermanfaat dan amal shalih.

Tuturan (1c) termasuk tindak tutur ilokusi jenis komisif yang sifatnya berjanji. Hal ini dapat diketahui dari tuturan penutur

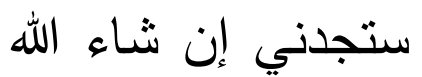
. Maksud tuturan tersebut adalah nabi Musa a.s. berjanji kepada Khidir bahwa ia akan bersabar atas apa yang ia lihat dari perbuatan-perbuatan Khidir dan tidak akan menentangnya dalam hal apapun.

Adapun tuturan (1d) penuturnya adalah Khidir. Tuturan ini termasuk tindak tutur ilokusi jenis deklaratif yang sifatnya menentukan, yakni menentukan syarat. Hal ini dapat diketahui dari tuturan penutur

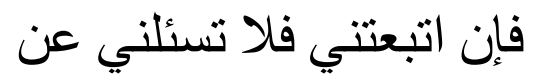
.ثيء حتى أحدث للك منه ذكرا Data tersebut memiliki maksud tuturan, Khidir mengizinkan nabi Musa a.s. membersamainya dengan syarat nabi Musa a.s. tidak akan menanyakan kejadian apapun sampai ia sendiri yang menjelaskannya.

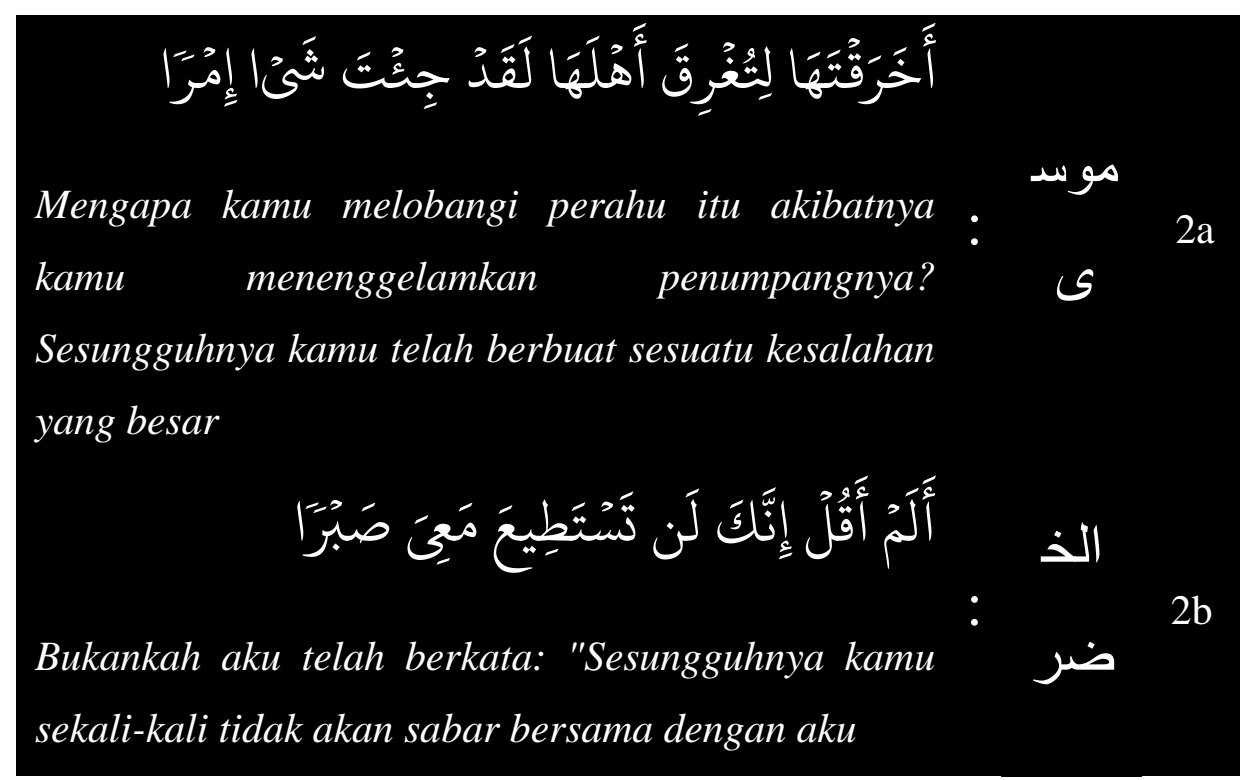




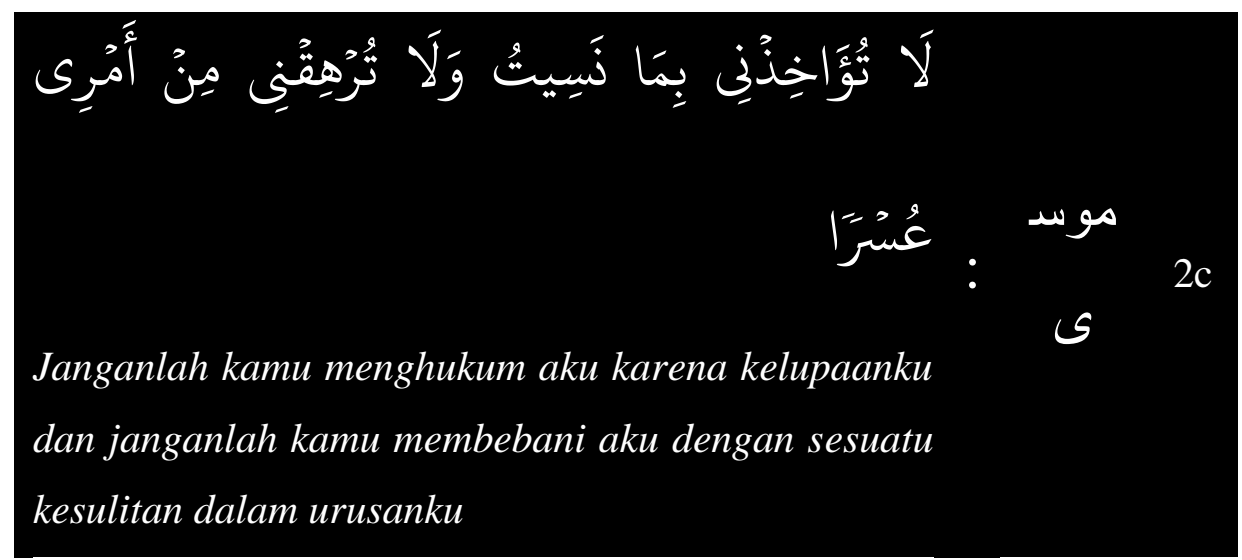

Percakapan di atas terjadi ketika nabi Musa a.s. dan Khidir berada di atas perahu yang sedang berlayar di tengah lautan. Kemudian Khidir melubangi perahu tersebut, padahal pemilik perahu itu membawa keduanya tanpa meminta upah sebagai bentuk penghormatan kepada Khidir. ${ }^{24}$ Tuturan (2b) penuturnya adalah Khidir dan mitra tuturnya adalah nabi Musa a.s. Tuturan tersebut termasuk tindak tutur ilokusi jenis direktif yang sifatnya menuntut. Hal ini dapat diketahui dari tuturan ألم أقل إنلك لن تستطبع معي صبرا Tuturan tersebut mengandung maksud, Khidir menuntut realisasi dari janji nabi Musa a.s. kepadanya bahwa ia akan bersabar atas apa yang ia lihat dari perbuatan-perbuatan Khidir dan tidak akan menentangnya dalam hal apapun serta menuntut kesanggupannya memenuhi syarat untuk tidak menanyakan kejadian apapun sampai Khidir sendiri yang menjelaskannya.

Adapun tuturan (2c) penuturnya adalah nabi Musa a.s. Tuturan tersebut termasuk tindak tutur ilokusi jenis direktif yang sifatnya memohon. Hal ini dapat diketahui dari tuturan تؤاخذني بما نسيث و لا تر هقني من أمري عسرا. Tuturan tersebut mengandung maksud, nabi Musa a.s. memohon kepada Khidir agar ia tidak menghukumnya karena telah menyalahi janji dan kesepakatan di antara keduanya yang disebabkan oleh lupa untuk pertama kalinya serta tidak mempersulit urusannya (belajar kepada Khidir).

\footnotetext{
${ }^{24}$ Ibid., 323.
} 


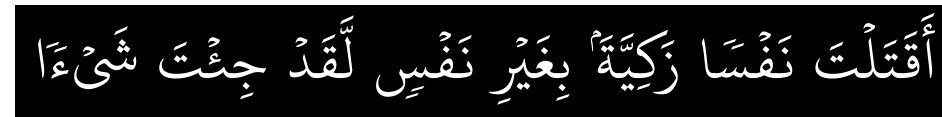

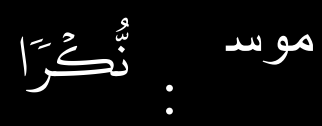

Mengapa kamu membunuh jiwa yang bersih, bukan

$\checkmark$

karena dia membunuh orang lain? Sesungguhnya

kamu telah melakukan suatu yang mungkar

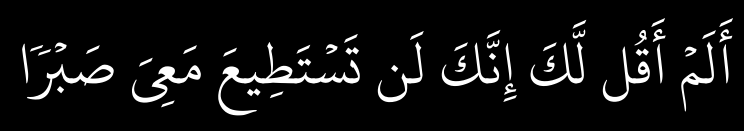

Bukankah sudah kukatakan kepadamu, bahwa :

sesungguhnya kamu tidak akan dapat sabar

bersamaku?

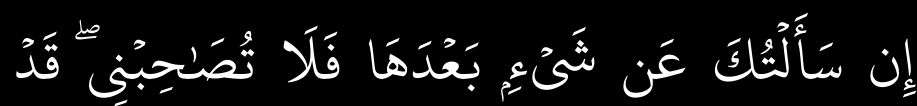

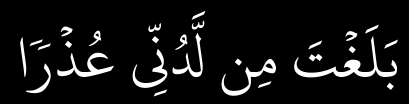

Jika aku bertanya kepadamu tentang sesuatu sesudah

(kali) ini, maka janganlah kamu memperbolehkan

aku menyertaimu, sesungguhnya kamu sudah cukup

memberikan uzur padaku

Percakapan di atas terjadi ketika Khidir membunuh seorang anak lakilaki yang tidak berdosa (tidak membunuh orang) yang ditemuinya di pesisir pantai selepas keduanya (nabi Musa a.s. dan Khidir) keluar dari perahu. ${ }^{25}$ Tuturan (3b) penuturnya adalah Khidir dan mitra tuturnya adalah nabi Musa a.s. Tuturan tersebut termasuk tindak tutur ilokusi jenis direktif yang sifatnya menuntut. Hal ini dapat diketahui dari tuturan ألم أقل للك إنك لن تستطبع معي صبرا. Tuturan tersebut mengandung maksud, Khidir menuntut realisasi dari janji nabi Musa a.s. kepadanya bahwa ia akan bersabar atas apa yang ia lihat dari perbuatanperbuatan Khidir dan tidak akan menentangnya dalam hal apapun serta menuntut

\footnotetext{
${ }^{25}$ Ibid., 324.
} 
kesanggupannya memenuhi syarat untuk tidak menanyakan kejadian apapun sampai Khidir sendiri yang menjelaskannya.

Adapun tuturan (3c) penuturnya adalah nabi Musa a.s. Tuturan tersebut termasuk tindak tutur ilokusi jenis komisif yang sifatnya menawarkan. Hal ini إن سألتك عن شيء بعدها فلا تصساحبني dapat diketahui dari tuturan penutur قد بلغت من لد لدني عذرا . Maksud tuturan tersebut adalah nabi Musa a.s. menawarkan solusi kepada Khidir berupa tidak lagi mengizinkannya (nabi Musa a.s.) menyertai Khidir apabila ia sampai menyalahi kesepakatan awal serta janjinya sekali lagi.

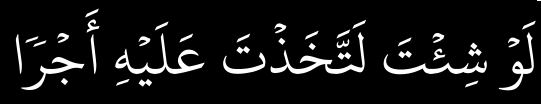

Jikalau kamu mau, niscaya kamu mengambil upah untuk itu

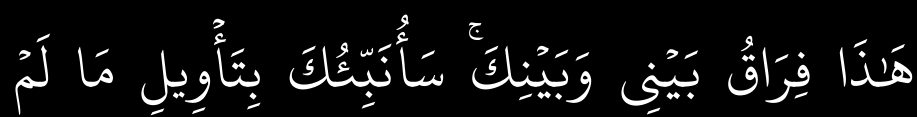

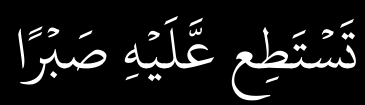

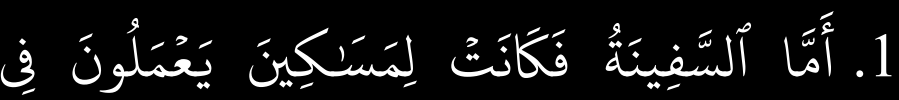

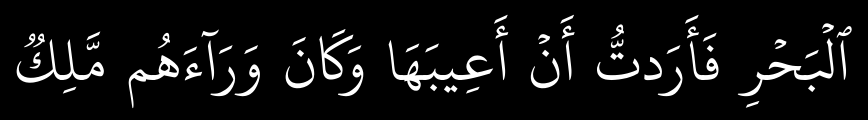

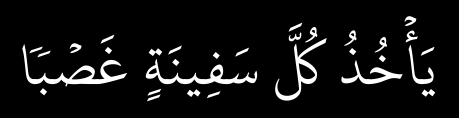

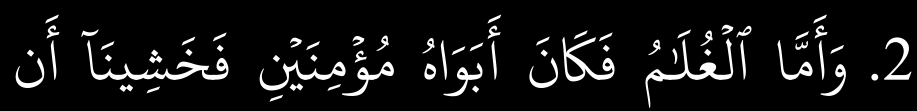

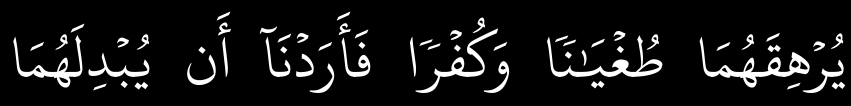

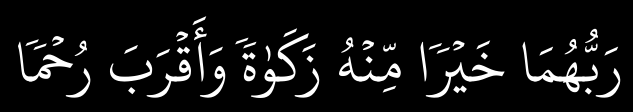



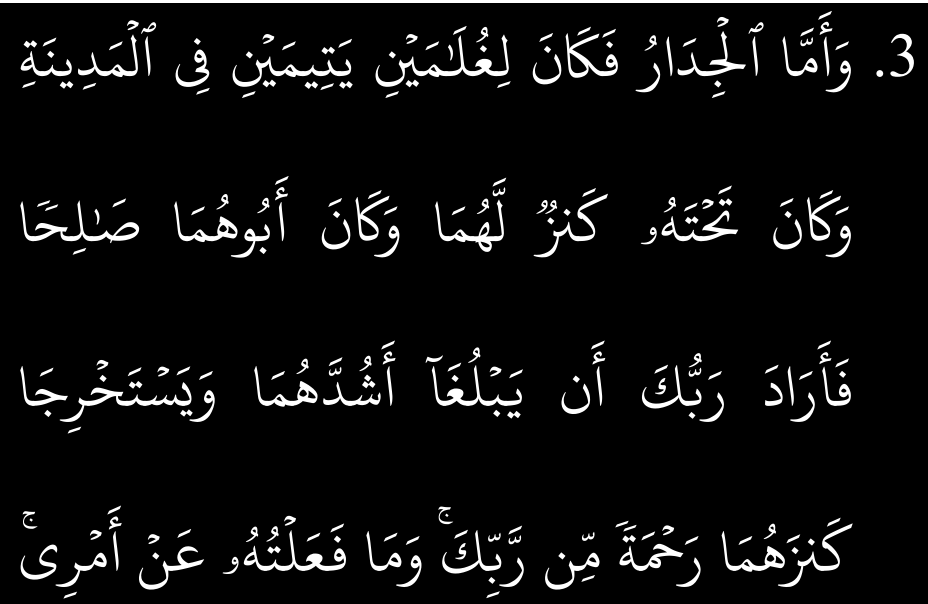

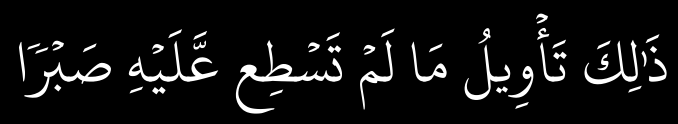

Inilah perpisahan antara aku dengan kamu; kelak akan kuberitahukan kepadamu tujuan perbuatanperbuatan yang kamu tidak dapat sabar terhadapnya

1. Adapun bahtera itu adalah kepunyaan orangorang miskin yang bekerja di laut, dan aku bertujuan merusakkan bahtera itu, karena di hadapan mereka ada seorang raja yang merampas tiap-tiap bahtera

2. Dan adapun anak muda itu, maka kedua orang tuanya adalah orang-orang mukmin, dan kami khawatir bahwa dia akan mendorong kedua orang tuanya itu kepada kesesatan dan kekafiran. Dan kami menghendaki, supaya Tuhan mereka mengganti bagi mereka dengan anak lain yang lebih baik kesuciannya dari anaknya itu dan lebih dalam kasih sayangnya (kepada ibu bapaknya)

3. Adapun dinding rumah adalah kepunyaan dua orang anak yatim di kota itu, dan di bawahnya ada harta benda simpanan bagi mereka berdua, sedang ayahnya adalah seorang yang saleh, maka Tuhanmu menghendaki agar supaya mereka sampai kepada kedewasaannya dan 
mengeluarkan simpanannya itu, sebagai rahmat

dari Tuhanmu; dan bukanlah aku melakukannya

itu menurut kemauanku sendiri. Demikian itu

adalah tujuan perbuatan-perbuatan yang kamu

tidak dapat sabar terhadapnya

Percakapan di atas terjadi antara nabi Musa a.s. dan Khidir ketika Khidir menegakkan dinding rumah yang hampir roboh di sebuah desa yang penduduknya tidak mau menjamu keduanya. ${ }^{26}$ Tuturan (4a) penuturnya adalah nabi Musa a.s. Tuturan tersebut termasuk tindak tutur ilokusi jenis direktif yang sifatnya menyarankan. Hal ini dapat diketahui dari tuturan لو ثُث لتخذت علبه أجرا. Tuturan tersebut mengandung maksud, nabi Musa a.s. menyarankan Khidir untuk meminta upah atas jasanya menegakkan kembali dinding rumah yang hampir roboh jika ia mau.

Tuturan (4b) penuturnya adalah Khidir dan mitra tuturnya adalah nabi Musa a.s. Tuturan tersebut termasuk jenis tuturan deklaratif yang sifatnya هذا فر اق بيني . Tuturan tersebut memiliki maksud, Khidir memberi hukuman kepada nabi Musa a.s. atas sikapnya yang menyalahi kesepakatan awal serta janjinya dengan mengakhiri kebersamaan keduanya.

\section{Penutup}

Berdasarkan analisis yang peneliti lakukan sebagaimana paparan di atas, maka dapat disimpulkan bahwa tindak tutur ilokusi yang terdapat pada percakapan nabi Musa a.s. dan Khidir ada tiga jenis, yakni direktif, komisif, dan deklaratif. Tindak tutur ilokusi direktif pada percakapan tersebut ada yang sifatnya meminta, menuntut, memohon, dan juga menyarankan. Tindak tutur ilokusi komisif ada yang sifatnya berjanji dan juga menawarkan. Sedangkan deklaratif pada percakapan tersebut bersifat menentukan dan memberi hukuman.

\footnotetext{
${ }^{26}$ Ibid., 336.
} 


\section{Daftar Pustaka}

al-Shabuni, Muhammad Ali. Shafwatu al-Tafasir Juz 2. Beirut: Dar al-Fikri, 1996.

al-Zuhailiy, Wahbah. al-Tafsir al-Munir Jilid 8. Damaskus: Dar al-Fikri, 2009.

Chaer, Abdul dan Leonie Agustina. Sosiolinguistik: Perkenalan Awal. Jakarta: Rineka Cipta, 2004.

Faisol, M. Struktur Naratif Cerita Nabi Khidir dalam al-Qur'an. Adabiyyat, Vol. X No.2 Desember 2011.

Fathurrosyid. Pragmatika al-Qur'an: Model Pemahaman Kisah Maryam yang Terikat Konteks. Jurnal Suhuf, Vol. 9 No. 2 Desember 2016.

Fauzi, Moch Sony. Pragmatik dan Ilmu Ma'aniy: Persinggungan Ontologik dan Epistemologik. Malang: UIN Maliki Press, 2012.

Idris, Mardjoko. Stilistika al-Qur'an: Kajian Pragmatik. Yogyakarta: KaryaMedia, 2013.

Leech, Geoffrey. Prinsip-prinsip Pragmatik, terj. M.D.D. Oka. Jakarta: Universitas Indonesia (UI Press), 2015.

Musfiroh, Tadkiroatun. Psikolinguistik Edukasional: Psikolinguistik untuk Pendidikan Bahasa. Yogyakarta: Tiara Wacana, 2017.

Nadar, F.X. Pragmatik \& Penelitian Pragmatik. Yogyakarta: Graha Ilmu, 2013.

Rofiq, Faiq Ainur. Analisa Redaksi Tindak Tutur Imperatif dalam Surat al-Baqarah. Jurnal Kodifikasia, Vol. 9 No. 12015.

Sumarsono. Sosiolinguistik. Yogyakarta: SABDA, 2011.

Tarigan, Henry Guntur. Pengajaran Pragmatik. Bandung: Angkasa, 2009.

Yule, George. Pragmatik, terj. Rombe Mustajab. Yogyakarta: Pustaka Pelajar, 2006. 